\title{
Study on Environmental Conditions of Seed Germination and Seedling Growth of Invasive Plant Amaranthus palmeri S. Watson
}

\author{
Haixia Han ${ }^{1,2}$, Xueying Li ${ }^{1}$, Tongtong Wang ${ }^{1}$, Fuchen $\mathrm{Shi}^{1 *}$ \\ ${ }^{1}$ College of Life Sciences, Nankai University, Tianjin 30071, China \\ ${ }^{2}$ School of Life Science and Technology, Jining Normal University, Ulanqab 012000, China
}

Received: 10 May 2021

Accepted: 25 June 2021

\begin{abstract}
To determine germination, seedling growth and vigor indices from the aspects of germination temperature, light, moisture, salt environment, and artificial aging, the germination test was performed on Amaranthus palmeri seeds under different environmental conditions. It was found that: i. Amaranthus palmeri seeds were capable of germinating at $15-40^{\circ} \mathrm{C}$, and germination rate (GR) increased as temperature increased; ii. Seedling growth rate was highest at $25^{\circ} \mathrm{C}$; iii. Light delayed seed germination and inhibited seedling growth; iv. Seed germination was inhibited when water potential was lower than $-0.32 \mathrm{MPa}$, while a very low GR was detected when water potential was lower than -1.10 MPa; v. Seed GR was inhibited at $4 \mathrm{~g} / \mathrm{L}$ salt levels, while seedling growth rates were strongly inhibited at $8 \mathrm{~g} / \mathrm{L}$ salinity; vi. Seed vigor was inhibited after artificial aging for 6 days, and all growth indices were inhibited after artificial aging for 15 days, however, germinability was $69 \%$. Amaranthus palmeri exhibited a higher risk of invasion in areas with hot and humid climates as well as with low degrees of soil salinization. Exposure of seeds to light can reduce the competitiveness of the Amaranthus palmeri population and seeds preserved in higher soil temperature can shorten their life.
\end{abstract}

Keywords: environmental condition, germination, growth, Amaranthus palmeri, intrusion

\section{Introduction}

Since alien invasive species can change the ecosystem, threaten the survival of native species, reduce biodiversity and damage the environment, there is a need to study the biological characteristics of harmful invasive species in order to develop

*e-mail: fcshi@nankai.edu.cn control measures. In 2016, Amaranthus palmeri was included in the "List of Alien Invasive Species in China's Natural Ecosystem (Batch 4)"[1]. Amaranthus palmeri is an annual herbaceous plant belonging to the Amaranthaceae family and Amaranthus genus [2]. It is a serious farm weed that rapidly grows to a height of 3 meters [3-5] and has a seed yield of 40,000-600,000 per plant [6, 7]. Originally, Amaranthus palmeri was a native herb of western United States and northern Mexico [8,9], which spread to various parts of Europe and Asia [6, 7, 10]. It was first discovered in 
Beijing, China in 1985 [11], and since 2013 it has been successively discovered in Tianjin [12], Shandong [13], Anhui [14], Jiangxi and in other Chinese provinces [15]. Its diffusion rate has a tendency to accelerate. Due to its strong adaptability and high genetic variability [16], Amaranthus palmeri can grow on farmlands [17], abandoned lands, in deserts [8], river beds [18], garbage dumps and on roadsides [19]. Invasion risk evaluations have shown that Amaranthus palmeri has a high risk of invasion in North China and Central China [10, 20, 21], which is the main grain producing area of China. If Amaranthus palmeri successfully invades this area, it will be difficult to control and will seriously threaten agricultural production.

Besides, Amaranthus palmeri has a strong ecological advantage in invaded areas. It begins to sprout once ground temperature is above $18^{\circ} \mathrm{C}$, and it rapidly grows after emergence. After 2 weeks of growth, the amount of its dry matter is $65 \%$ higher than that of the other invasive plant Amaranthus spinosus, while at 2 weeks and 4 weeks, it is at least $37 \%$ and $45 \%$ bigger in height than the Amaranthus spinosus, respectively [4,5]. Amaranthus palmeri produces viable seeds within a very short time [5]. The leaf area of Amaranthus palmeri is similar to that of corn, while being more competitive in photosynthesis than that of corn [22]. If removed before flowering, Amaranthus palmeri can still affect soybean yields [9]. When the density of Amaranthus palmeri reaches 8 plants per meter in rows, soybean yields reduce by about $80 \%$ [17]. Therefore, Amaranthus palmeri is superior to short and tall crops in both growth rate and space occupancy, which seriously affects the growth and development of these crops. Besides, Amaranthus palmeri is resistant to glyphosate and imazethapyr herbicides [15, 23], and is therefore, difficult to control using chemicals.

Amaranthus palmeri is characterized by fast seed production, a high seed yield and strong adaptability. For effective control, it is important to prevent the spread of its seeds. Therefore, it is important to characterize these seeds in terms of temperature, light, moisture, salt, and aging resistance [7].

Amaranthus palmeri prefers high temperatures, grows faster after germination, and accumulates more seedling biomass under high temperatures. Moreover, it has the highest net photosynthetic rate when leaf temperature reaches $42^{\circ} \mathrm{C}$ [8]; when temperatures increase from $15^{\circ} \mathrm{C}$ to $30^{\circ} \mathrm{C}$, seed germination rates increase linearly [24]; while at $30^{\circ} \mathrm{C} / 35^{\circ} \mathrm{C}$, germination rates and seedling biomass is at its highest [25]. Fresh and mature seeds cannot germinate below $25^{\circ} \mathrm{C}$ [26]. Amaranthus palmeri seeds have a higher germination rate than Amaranthus spinosus and Amaranthus tuberculatus [27]. In the Amaranthus family, Amaranthus palmeri, Amaranthus retroflexus, and Amaranthus spinosus have a similar upper germination temperature at about $40^{\circ} \mathrm{C}$ [25, 28, 29]. After germination, Amaranthus palmeri seedlings grow faster than other Amaranthus species, which may be correlated with its fast germination speed [4, 22, 24].

During storage, the vigor of Amaranthus palmeri seeds may be damaged by light to a certain extent. Amaranthus palmeri seeds on the surfaces of Illinois and Missouri soils in the United States have been shown to seriously lose their vigor than those below the soils [19], while seeds exposed to light have a high germination rate $[19,26]$. Conversely, weed seeds of the Amaranthus congeners exhibit diverse light requirements during the germination stage [16]. Seed germination rates of Amaranthus retroflexus, Amaranthus spinosus, Amaranthus blitum and other plants obtained from China are affected by light in different ways [28, 30]. Light promotes the seed germination rate of Amaranthus retroflexus while inhibiting seed germination rates of Amaranthus viridis. The other plants are not effected by light [28, 30].

Amaranthus palmeri is strongly adaptable to water environments, and its seeds are strongly resistant to water logging. In areas where precipitation is between $130 \mathrm{~mm}$ and $730 \mathrm{~mm}$ [31], Amaranthus palmeri seeds can still maintain a germination rate of $86 \%$ after 5 months of water logging [18]. Amaranthus palmeri can grow normally when soil moisture levels reach $100 \%$ of soil field capacity. Moreover, when soil moisture reaches $25 \%$ of soil field capacity, Amaranthus palmeri can survive for 35 days under severe drought [32]. Its adaptability to drought is associated with its priority to developing root system [22].

Weed germination and seedling growth rates are usually affected by soil salinity and persistence of soil seed banks. Inhibitory effects of different salt concentrations on Amaranthus seeds varies from species to species. Germination rates of Amaranthus retroflexus, Amaranthus blitoides, and Amaranthus albus are significantly inhibited at $0.29 \%$ salinity [33], while germination rates of Amaranthus cruentus and Amaranthus tricolor are inhibited at $0.4 \%$ and $0.5 \%$ salinity, respectively [34, 35]. Compared to Amaranthus hybridus, Amaranthus viridis and Amaranthus tricolor, Amaranthus giganticus seeds have been shown to exhibit stronger salt resistance [36]. In addition, seed bank persistence is affected by many environmental factors, among which temperature and humidity are the most important [19, 37]. Therefore, to evaluate seed life, artificial aging is often accelerated in a high-temperature and high-humidity environment [38, 39]. This is of great significance when evaluating the invasion potential of Amaranthus palmeri seeds and in formulating control measures.

Amaranthus palmeri whose origin is the United States has different ecotypes [40]. However, after being introduced into China for 36 years, its adaptability to the ecological environment may be different from that of the original population. In recent years, Amaranthus palmeri has been spreading wildly in China. However, it's still unknown whether its spreading ability is correlated with its adaptability to environmental 
factors. Few studies have evaluated the response of Amaranthus palmeri seeds to multiple environmental conditions during the germination and seedling stages. In this study, using wild Amaranthus palmeri seeds as the experimental material, temperature, light, moisture, and salt conditions as well as seed aging characteristics were evaluated to establish the impact of several environmental factors on germination and seedling growth rates. Moreover, its invasion potential was evaluated. This study provides scientific and theoretical bases for the prediction of Amaranthus palmeri's distribution and formulation of preventive and control strategies.

\section{Experimental}

\section{Materials and Methods}

\section{Experimental Material}

Natural Amaranthus palmeri seeds were collected in Xiqing District, Tianjin in 2019 and air-dried in the dark for 4 weeks in the laboratory. After threshing, they were stored in kraft paper sacks at room temperature.

\section{Methods}

Determination of the effects of temperature ranges on Amaranthus palmeri seed germination: Using a double-layered filter paper as the germination bed, the germination test was performed using the petri dish method. Amaranthus palmeri seeds were placed at different temperatures to germinate in dark, and temperatures were set as $10,15,20,25,30,35,40$, and $45^{\circ} \mathrm{C}$. Evaporated water was supplied daily. By setting the radicle length $>1 / 2$ seed radius as the germination standard, germination statuses of Amaranthus palmeri seeds were recorded every day, germination potential (GP) were recorded from 1st day, while germination rate (GR) were recorded at the $5^{\text {th }}$ day. In addition, radicle lengths, hypocotyl lengths, and fresh weight of seedlings were measured, after which germination index (GI) and vigor index (VI) were calculated.

Determination of the effects of light conditions during the germination stage of Amaranthus palmeri seeds: The germination test was performed by using Petri dishes at a temperature of $25^{\circ} \mathrm{C}$. Seeds were placed under different lighting conditions: $24 \mathrm{~h}$ light, $12 / 12 \mathrm{~h}$ light/dark, $24 \mathrm{~h}$ dark. Procedures for determining germination and seedling biomass indices were the same as above.

Determination of the effects of moisture conditions during the germination stage of
Amaranthus palmeri seeds: Different concentrations of PEG6000 solutions were prepared to simulate different water potential environments. The correspondence between PEG6000 concentrations and water potential is shown in Table 1. After disinfection, Amaranthus palmeri seeds were placed on a germination bed with three layers of filter papers to germinate. The same volume of PEG6000 solution was added to Petri dishes, which were then covered with sealed bags to reduce water evaporation. After evaporation, water was supplemented on the next day. The same volume of deionized water was used as the control. The Petri dish method was used to perform the germination test at a germination temperature of $25^{\circ} \mathrm{C}$. Procedures for determining germination and seedling biomass indices were the same as above.

Determination of the effects of salt conditions during the germination stage of Amaranthus palmeri seeds: Different concentrations of $\mathrm{NaCl}$ solution were prepared: 4, 8, $12 \mathrm{~g} / \mathrm{L}$, and the same volume of solution was added to the Petri dishes. Seeds were placed on the germination bed with three layers of filter papers to germinate, after which Petri dishes were covered with sealed bags to inhibit water evaporation. Evaporated water was supplemented on the next day. The same volume of deionized water was used as the control. The Petri dish method was used to perform the germination test at $25^{\circ} \mathrm{C}$. Determination of germination and seedling biomass indices were done as above.

Effects of artificial aging on Amaranthus palmeri seed germination: Amaranthus palmeri seeds were placed in a mesh bag, after which they were placed in a climate box at a temperature of $50^{\circ} \mathrm{C}$ and a relative humidity of $100 \%$ to establish artificial aging [38]. The Petri dish method was used to perform the germination test at a germination temperature of $25^{\circ} \mathrm{C}$ after artificial aging for $3,6,9,12,15$ days, and after evaporation, water was added every day. Amaranthus palmeri seeds without aging treatment were used as controls. Germination and seedling biomass indices were determined as above.

\section{Statistical Analysis}

Explanation:

$$
\mathrm{GP}=\mathrm{N}_{1} / \mathrm{N}_{\mathrm{t}}^{*} 100
$$

GP: Germination potential (\%)

$\mathrm{N}_{1}$ : the number of germinated seeds in the $1^{\text {st }}$ day

$\mathrm{N}_{\mathrm{t}}$ : total tested sample seeds

Explanation:

$$
\mathrm{GR}=\mathrm{N}_{5} / \mathrm{N}_{\mathrm{t}} * 100
$$

Table 1. Correspondence between different concentrations of PEG6000 solution and water potential.

\begin{tabular}{|c|c|c|c|c|c|c|c|}
\hline Concentration of PEG6000 solution g/L & 0 & 50 & 100 & 150 & 200 & 250 & 300 \\
\hline Water potential MPa & 0 & -0.06 & -0.17 & -0.32 & -0.53 & -0.79 & -1.10 \\
\hline
\end{tabular}


GR: Germination rate (\%)

$\mathrm{N}_{5}$ : the number of germinated seeds in the $5^{\text {th }}$ day

$\mathrm{N}_{\mathrm{t}}$ : total tested sample seeds

$$
\begin{aligned}
\mathrm{GI} & =\left(\mathrm{G}_{1} / \mathrm{D}_{1}+\mathrm{G}_{2} / \mathrm{D}_{2}+\mathrm{G}_{3} / \mathrm{D}_{3}\right. \\
& \left.+\mathrm{G}_{4} / \mathrm{D}_{4}+\mathrm{G}_{5} / \mathrm{D}_{5}\right) * 100
\end{aligned}
$$

Explanation:

GI: Germination index

Gi: the percentage of seed germination in $\mathrm{i}$ day $(1 \leqq \mathrm{i} \leqq 5)$

Di: the corresponding germination day $(1 \leqq i \leqq 5)$

Explanation:

$$
\mathrm{VI}=\mathrm{GI} * \mathrm{~L}_{\mathrm{s}}
$$

VI: Vigor index

GI: Germination index

$\mathrm{L}_{\mathrm{s}}$ : total length of seedlings ( $\left.\mathrm{mm}\right)$

Data was entered in Excel 2007, and transported to SPSS 22.0 for statistical analysis using the analysis of variance.

\section{Results and Discussion}

\section{Effects of Different Temperatures on Amaranthus palmeri Seed Germination and Seedling Growth}

Amaranthus palmeriseeds exhibited different germination trends under different temperature conditions (Fig. 1). They had an ability to germinate at $15^{\circ} \mathrm{C} \sim 40^{\circ} \mathrm{C}$, while lacking the ability to germinate at $10^{\circ} \mathrm{C}$ and $45^{\circ} \mathrm{C}$. GR, GP and GI of Amaranthus palmeri seeds were highest at $40^{\circ} \mathrm{C}$. Statistically, $30^{\circ} \mathrm{C} \sim 40^{\circ} \mathrm{C}$ was the most conducive temperature for germination $(\mathrm{p}<0.05)$. GP and GI were used to determine seed germination speed and uniformity. Germination

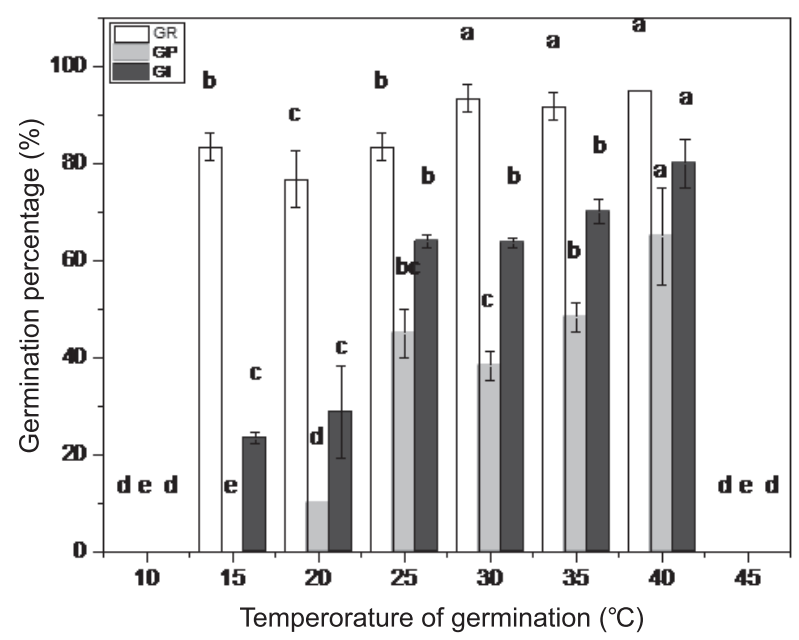

Fig. 1. Germination indices of Amaranthus palmeri seeds under different temperatures conditions (Note: Lowercase letters in the figure are results from ANOVA and Duncan's test among treatments with the same index; different letters indicate significant differences $(P<0.05)$; error bars indicate standard deviations. The following are the same.) uniformity was highest at $40^{\circ} \mathrm{C}$, and lowest at $15^{\circ} \mathrm{C} \sim 20^{\circ} \mathrm{C}$.

With increasing temperature, hypocotyl length, radicle length, and seedling fresh weight of Amaranthus palmeri seedlings changed to a certain extent (Table 2). At $25^{\circ} \mathrm{C}$, Amaranthus palmeri seedlings grew better and exhibited the strongest vigor. At $20^{\circ} \mathrm{C}$, the increases in hypocotyl length as well as VI were inhibited. When temperature was lower than $15^{\circ} \mathrm{C}$, all growth indices were significantly restricted $(P<0.05)$; when temperature was higher than $35^{\circ} \mathrm{C}$, length and vigor were inhibited, while fresh weights of seedlings were not inhibited. That is, $25^{\circ} \mathrm{C}$ is the most suitable temperature for the growth of Amaranthus palmeri seedlings, while temperatures lower than $20^{\circ} \mathrm{C}$ or higher than $35^{\circ} \mathrm{C}$ inhibit their growth.

Amaranthus palmeri has a wide temperature adaptability, and Amaranthus palmeri from different sources exhibit differences [41]. Amaranthus palmeri seeds from California, Manhattan, and South Carolina have been shown to have a minimum germination temperature of $15^{\circ} \mathrm{C}$, and a maximum germination temperature of $40^{\circ} \mathrm{C}$ or $45 / 40{ }^{\circ} \mathrm{C}$ (day/night) [24, 25], which is comparable to our findings. However, there were differences. First, there were differences in germination rates at $40^{\circ} \mathrm{C}$. In this study, germination rate and germination speed of Amaranthus palmeri seeds increased with increasing temperature; but the germination rate of the seeds from the United States is only half of $25^{\circ} \mathrm{C}$ at $40^{\circ} \mathrm{C}$ [25]. This could be attributed to the fact that vigor of the tested seeds is low as the best germination rate only $50 \%$, with some of the vigor being inhibited by other factors, or Amaranthus palmeri has an increased tolerance to high summer temperatures after long-term migration to China. Second, optimum growth temperature for seeds from Manhattan is $35 / 30^{\circ} \mathrm{C}$, while the optimum growth temperature for the growth of Amaranthus palmeri root in this study was $25^{\circ} \mathrm{C}$ [25]. This could be attributed to adaptation of Chinese seeds to a larger daily range of temperatures, which maintains their potential to grow at lower temperatures [42]. In terms of maximum germination temperature, Amaranthus palmeri is similar to invasive plants Amaranthus retroflexus and Amaranthus spinosus, but is different from other non-invasive species such as Amaranthus viridis and Amaranthus blitum [28, 43, 44]. Amaranthus palmeri seeds from Tianjin could not germinate at temperatures below $15^{\circ} \mathrm{C}$ or higher than $40^{\circ} \mathrm{C}$. Therefore, in terms of temperature factors, Amaranthus palmeri has an intrusion risk in most areas of North China and Central China.

\section{Effects of Different Light Conditions on Amaranthus palmeri Seed Germination and Seedling Growth}

Under different light conditions, germination curves of Amaranthus palmeri were separated on the $1^{\text {st }}$ day. The rate of germination under different treatments was 
Table 2. Growth and vigor indices of Amaranthus palmeri seedlings at different temperatures.

\begin{tabular}{|c|c|c|c|c|c|c|}
\hline TEMP $^{\circ} \mathrm{C}$ & HL mm & RL mm & SLmm & SFW mg & RRH & VI \\
\hline 15 & $3.5 \pm 1.1 \mathrm{~d}$ & $10.1 \pm 3.1 \mathrm{~d}$ & $13.6 \pm 3.9 \mathrm{e}$ & $1.95 \pm 0.27 \mathrm{~b}$ & $2.95 \pm 0.90 \mathrm{a}$ & $319 \pm 94 \mathrm{e}$ \\
\hline 20 & $19.0 \pm 3.8 \mathrm{~b}$ & $29.5 \pm 6.8 \mathrm{a}$ & $48.5 \pm 9.4 \mathrm{bc}$ & $3.76 \pm 0.10 \mathrm{a}$ & $1.58 \pm 0.35 \mathrm{~b}$ & $1395 \pm 500 \mathrm{~d}$ \\
\hline 25 & $25.5 \pm 3.9 \mathrm{a}$ & $28.8 \pm 2.0 \mathrm{a}$ & $54.3 \pm 4.7 \mathrm{a}$ & $3.98 \pm 0.31 \mathrm{a}$ & $1.16 \pm 0.19 \mathrm{c}$ & $3465 \pm 275 \mathrm{a}$ \\
\hline 30 & $23.6 \pm 3.0 \mathrm{a}$ & $27.1 \pm 4.1 \mathrm{a}$ & $50.7 \pm 6.3 \mathrm{ab}$ & $3.95 \pm 0.12 \mathrm{a}$ & $1.15 \pm 0.16 \mathrm{c}$ & $3225 \pm 384 \mathrm{ab}$ \\
\hline 35 & $20.8 \pm 1.8 \mathrm{~b}$ & $23.6 \pm 4.2 \mathrm{~b}$ & $44.4 \pm 5.6 \mathrm{c}$ & $3.79 \pm 0.04 \mathrm{ab}$ & $1.13 \pm 0.15 \mathrm{c}$ & $3099 \pm 341 \mathrm{~b}$ \\
\hline 40 & $15.2 \pm 3.9 \mathrm{c}$ & $14.6 \pm 2.7 \mathrm{c}$ & $29.8 \pm 5.9 \mathrm{~d}$ & $2.68 \pm 0.04 \mathrm{ab}$ & $1.00 \pm 0.22 \mathrm{c}$ & $2370 \pm 419 \mathrm{c}$ \\
\hline
\end{tabular}

* TEMP $=$ Temperature, $\mathrm{HL}=$ Hypocotyl length, $\mathrm{RL}=$ Radicle length, $\mathrm{SL}=$ Seedling length, $\mathrm{SFW}=$ Seedling fresh weight, $\mathrm{RRH}=$ Ratio of radicle length to hypocotyl length, $\mathrm{VI}=$ vigor index .

similar between days 2 5 (Fig. 2a). On the $1^{\text {st }}$ day of germination, GP of seeds under $24 \mathrm{~h}$ dark treatment was significantly higher than those of seeds under 12 $\mathrm{h}$ light $/ 12 \mathrm{~h}$ dark and $24 \mathrm{~h}$ light. GR on the $5^{\text {th }}$ day were not significantly different among the treatments (Fig. 2b). Light exhibited a certain delay effect on the germination of Amaranthus palmeri seeds, but did not affect the final GR.

Under different light conditions, the growth rate of Amaranthus palmeri seedlings decreased in the order of

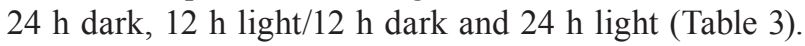
Hypocotyl length, radicle length, total seedling length and hypocotyl length/radicle length under $24 \mathrm{~h}$ light treatment were significantly lower than those of other treatments $(P<0.05)$. There were significant differences in seedling fresh weights among the three treatments $(P<0.05)$. In conclusion, light has an inhibitory effect on biomass accumulation of Amaranthus palmeri seedlings.

Amaranthus palmeri seeds from different sources have different light requirements, and the population introduced in China responds negatively to the presence of light. In this study, treatment of Amaranthus palmeri seeds with visible light for $12 \mathrm{~h}$ light/ $12 \mathrm{~h}$ dark or 24 $\mathrm{h}$ light during the germination stage did not affect the germination rate, but delayed seed germination and inhibited seedling growth and vigor. Germination of Amaranthus palmeri seeds from South Carolina is promoted by natural light (the germination rate is $16 \%$ ), but is inhibited by darkness (the germination rate is $6 \%$ ), and the effects of the two are reversible [26, 45]. Its germination speed and seedling growth have not been studied, which needs further verification. In this study, we found that Amaranthus palmeri seeds germination speed and seedling growth speed were inhibited by light. In natural environments, Amaranthus palmeri seeds germinating on the soil surface grow slower than seeds covered by soil, which is not conducive for the rapid survival of Amaranthus palmeri, and lowers the growth rate of Amaranthus palmeri in no-tillage fields or wastelands, consistent with findings of previous studies $[7,46]$. Seed germination rates of invasive plants, a)

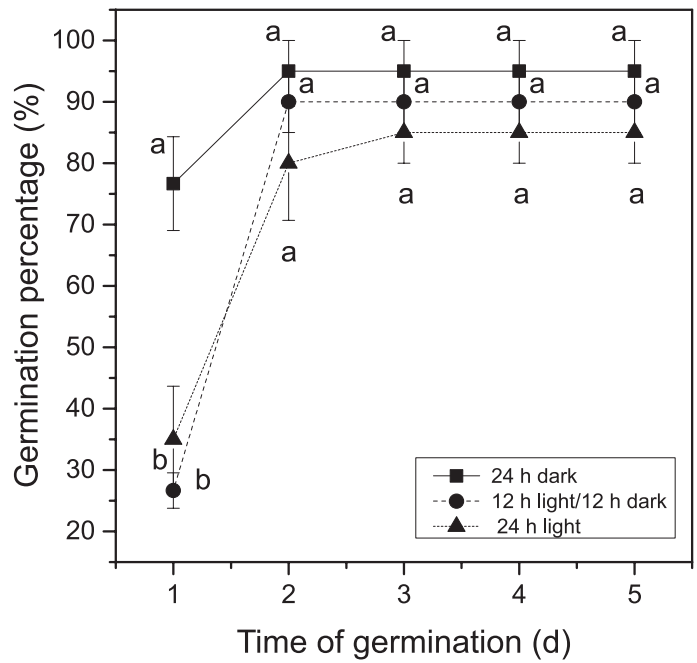

b)

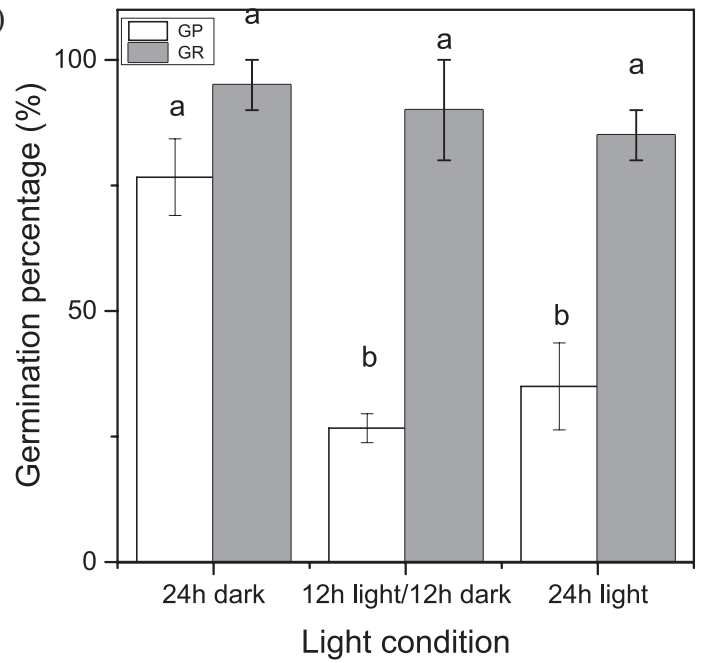

Fig. 2. The germination curve a) of Amaranthus palmeri seeds within 5 days and b) germination potential and germination rates of the seeds under different light conditions. Different lowercase letters in the figure are results from ANOVA and Duncan's test among different treatment within the same index $(P<0.05)$. 
Table 3. Growth and vigor indices of Amaranthus palmeri seedlings at different light conditions.

\begin{tabular}{|c|c|c|c|c|c|c|}
\hline LC & HL mm & RL mm & SLmm & SFW mg & RRH & VI \\
\hline 24 h dark & $15.9 \pm 3.9 \mathrm{a}$ & $33.6 \pm 5.9 \mathrm{a}$ & $49.5 \pm 8.1 \mathrm{a}$ & $3.10 \pm 0.28 \mathrm{a}$ & $2.21 \pm 0.57 \mathrm{a}$ & $4252 \pm 738 \mathrm{a}$ \\
\hline $12 / 12 \mathrm{~h} \mathrm{light/dark}$ & $15.6 \pm 3.2 \mathrm{a}$ & $32.3 \pm 4.8 \mathrm{a}$ & $47.8 \pm 6.7 \mathrm{a}$ & $2.67 \pm 0.14 \mathrm{~b}$ & $2.17 \pm 0.68 \mathrm{a}$ & $3645 \pm 1177 \mathrm{~b}$ \\
\hline $24 \mathrm{~h} \mathrm{light}$ & $11.4 \pm 1.3 \mathrm{~b}$ & $19.1 \pm 2.6 \mathrm{~b}$ & $30.5 \pm 2.9 \mathrm{~b}$ & $2.21 \pm 0.11 \mathrm{c}$ & $1.70 \pm 0.32 \mathrm{~b}$ & $1802 \pm 224 \mathrm{c}$ \\
\hline
\end{tabular}

$* \mathrm{LC}=$ Light condition, $\mathrm{HL}=$ Hypocotyl length, $\mathrm{RL}=$ Radicle length, $\mathrm{SL}=$ Seedling length, $\mathrm{SFW}=$ Seedling fresh weight, $\mathrm{RRH}=$ Ratio of radicle length to hypocotyl length, $\mathrm{VI}=$ vigor index.

Amaranthus retroflexus and Amaranthus spinosus, are not affected by photoperiods [28]. Exposure to light should be increased after Amaranthus palmeri seeds have matured and fallen to the ground. There are no effective tillage strategies that are beneficial in reducing the invasive pressure of Amaranthus palmeri [16, 47, 48].

\section{Effects of Different Water Conditions on Amaranthus palmeri Seed Germination and Seedling Growth}

In the PEG environment with a concentration gradient of $50 \sim 300 \mathrm{~g} / \mathrm{L}$ (water potential: -0.06 -1.10 MPa), germination curves of Amaranthus palmeri seeds show significant separation after 1 5 days, which stabilized after 2 days (Fig. 3). On the $5^{\text {th }}$ day of germination, GR among various treatments were statistically divided into 4 echelons, from high to low $(P<0.05): 0 \sim 100 \mathrm{~g} / \mathrm{L}$, $150 \mathrm{~g} / \mathrm{L}, 200 \sim 250 \mathrm{~g} / \mathrm{L}$, and $300 \mathrm{~g} / \mathrm{L}$. GR at $150 \mathrm{~g} / \mathrm{L}$ and $300 \mathrm{~g} / \mathrm{L}$ were reduced by $16 \%$ and $96 \%$, respectively. When PEG concentration was higher than $150 \mathrm{~g} / \mathrm{L}$ (water potential was lower than $-0.32 \mathrm{MPa}$ ), GR of Amaranthus palmeri seeds was significantly inhibited and when PEG concentration was higher than $300 \mathrm{~g} / \mathrm{L}$ (water potential was lower than -1.10 Mpa), Amaranthus palmeri could almost not germinate.

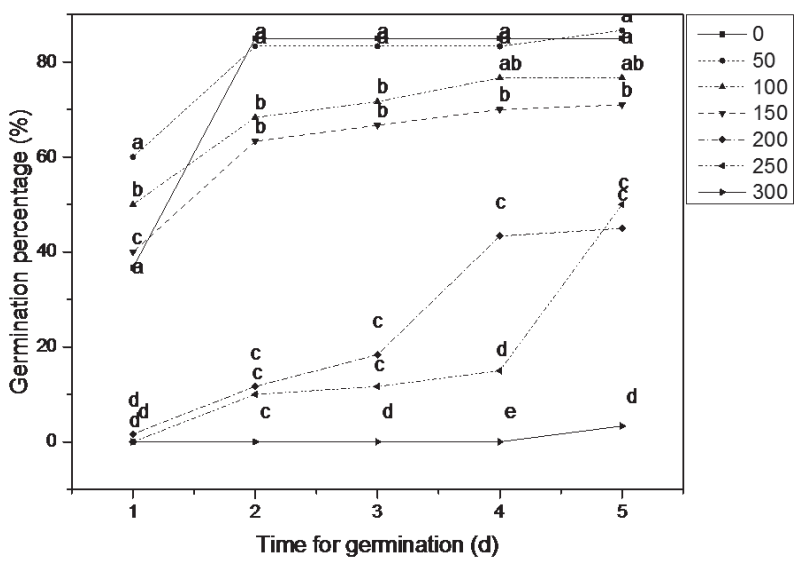

Fig. 3. Germination curve of Amaranthus palmeri seeds under different concentration of PEG6000 within 5 days, lowercase letters in the figure are results from ANOVA and Duncan's test among different treatment at the same germination time $(P<0.05)$
With increasing PEG concentrations from $50 \mathrm{~g} / \mathrm{L}$ to $300 \mathrm{~g} / \mathrm{L}$, environmental water potential gradually decreased and radicle length, hypocotyl length, total seedling length and vigor index of Amaranthus palmeri seedlings exhibited a trend of small increase at the beginning and then, a decrease (Table 4). Statistically, when PEG concentration was higher than $150 \mathrm{~g} / \mathrm{L}$, hypocotyl length and vigor index were significantly low than those of the control group, while ratio of radicle to hypocotyl length significantly increased. When PEG concentration was higher than $200 \mathrm{~g} / \mathrm{L}$, radicle length and total seedling length of Amaranthus palmeri were significantly lower than those of the control group $(p<0.05)$. In brief, when PEG concentration was higher than $150 \mathrm{~g} / \mathrm{L}$ (water potential is lower than $-0.32 \mathrm{MPa}$ ), the growth of Amaranthus palmeri seedlings was inhibited by varying degrees.

Amaranthus palmeri seeds exhibit a certain adaptability to changes in water potential during germination. At a water potential of $0 \mathrm{MPa}$, Amaranthus palmeri seeds have a high germination rate and grow normally; at a water potential of $-0.32 \mathrm{MPa}$, germination of Amaranthus palmeri seeds as well as seedling growth are inhibited while at a water potential of $-1.10 \mathrm{MPa}$, Amaranthus palmeri seeds only have 3.3\% of germination rate. The invasive plant, Amaranthus spinosus, cannot germinate at a water potential of -0.6 MPa [29]. Amaranthus cruentus and Amaranthus hypochondriacus germinate slowly at a water potential of -0.9 $\mathrm{MPa}$ [49,50], while Amaranthus tricolor, Amaranthus cruentus and Amaranthus hypochondriacus cannot germinate at a water potential of $-1.2 \mathrm{MPa}[49$, 51]. Drought resistance of seeds is similar to adaptability of plants to drought [32, 52, 53]. Amaranthus palmeri's adaptability to low water potential is stronger than that of Amaranthus spinosus, and similar to that of Amaranthus cruentus and Amaranthus tricolor. During invasion, Amaranthus palmeri adapts to dry seasons or regions, and has a wider range of water adaptability than Amaranthus spinosus.

\section{Effects of Different Salt Concentrations on Amaranthus palmeri Seed Germination and Seedling Growth}

At $4 \mathrm{~g} / \mathrm{L}$ salinity, germination percentage of Amaranthus palmeri seeds was significantly inhibited (Fig. 4). Moreover, the GR was significantly suppressed 
Table 4. Growth and vigor indices of Amaranthus palmeri seedlings under different water conditions.

\begin{tabular}{|c|c|c|c|c|c|}
\hline PC g/L & HL mm & RL mm & SL mm & RRH & VI \\
\hline 0 & $25.5 \pm 4.0 \mathrm{a}$ & $28.8 \pm 2.0 \mathrm{a}$ & $54.3 \pm 4.7 \mathrm{a}$ & $1.16 \pm 0.2 \mathrm{bc}$ & $3300 \pm 271 \mathrm{a}$ \\
\hline 50 & $26.0 \pm 4.8 \mathrm{a}$ & $27.2 \pm 6.0 \mathrm{a}$ & $53.2 \pm 8.9 \mathrm{a}$ & $1.07 \pm 0.3 \mathrm{c}$ & $3690 \pm 681 \mathrm{a}$ \\
\hline 100 & $27.5 \pm 8.1 \mathrm{a}$ & $32.8 \pm 8.9 \mathrm{a}$ & $60.4 \pm 16.4 \mathrm{a}$ & $1.21 \pm 0.2 \mathrm{bc}$ & $3932 \pm 1046 \mathrm{a}$ \\
\hline 150 & $17.7 \pm 5.8 \mathrm{~b}$ & $30.1 \pm 7.6 \mathrm{a}$ & $47.8 \pm 12.4 \mathrm{a}$ & $1.79 \pm 0.5 \mathrm{~b}$ & $2645 \pm 599 \mathrm{~b}$ \\
\hline 200 & $6.4 \pm 6.8 \mathrm{c}$ & $15.3 \pm 11.5 \mathrm{~b}$ & $21.7 \pm 18.6 \mathrm{~b}$ & $3.09 \pm 1.0 \mathrm{a}$ & $337 \pm 280 \mathrm{c}$ \\
\hline 250 & $8.3 \pm 4.2 \mathrm{c}$ & $13.1 \pm 3.6 \mathrm{~b}$ & $21.46 .77 .3 \mathrm{~b}$ & $1.77 \pm 0.6 \mathrm{~b}$ & $281 \pm 109 \mathrm{c}$ \\
\hline 300 & $3.5 \pm 4.4 \mathrm{c}$ & $9.5 \pm 11.4 \mathrm{~b}$ & $13.0 \pm 15.8 \mathrm{~b}$ & $3.07 \pm 0.6 \mathrm{a}$ & $13 \pm 16 \mathrm{c}$ \\
\hline
\end{tabular}

$* \mathrm{PC}=$ PEG6000 concentrations, $\mathrm{HL}=$ Hypocotyl length, $\mathrm{RL}=$ Radicle length, $\mathrm{SL}=$ Seedling length, $\mathrm{RRH}=$ Ratio of radicle length to hypocotyl length, $\mathrm{VI}=$ vigor index.

( $<<0.05$ ), and was only $84 \%$ of the control value. Seedling growth and VI did not change significantly (Table 5). At $8 \mathrm{~g} / \mathrm{L}$ salt concentration, the GR was $12 \%$ of the control value, and both seed GI as well as seedling growth index were significantly suppressed $(\mathrm{p}<0.05$; Table 5$)$. In conclusion, $4 \mathrm{~g} / \mathrm{L}$ salinity has an inhibitory effect on the GR of Amaranthus palmeri seeds, while $8 \mathrm{~g} / \mathrm{L}$ salinity strongly inhibits seed germination and seedling growth of Amaranthus palmeri. Amaranthus spinosus

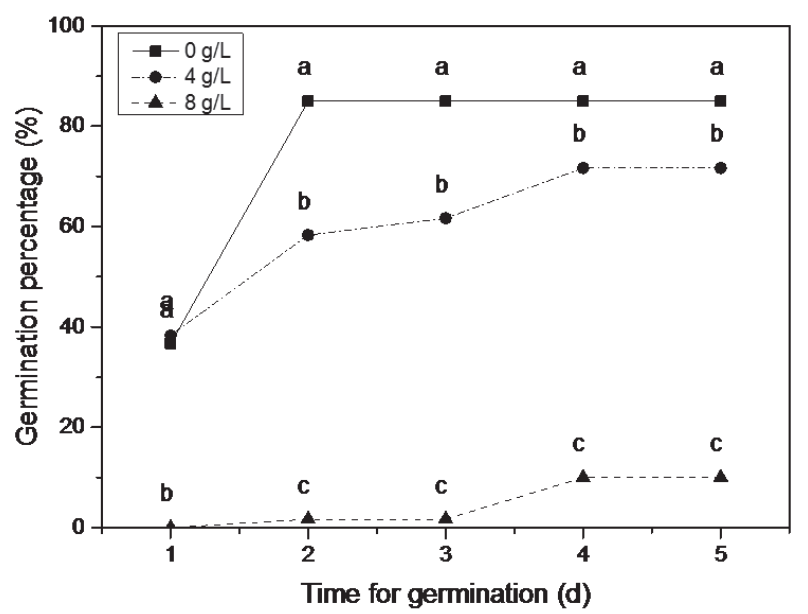

Fig. 4. Germination curve of Amaranthus palmeri seeds under different concentration of salt within 5 days, lowercase letters in the figure are results from ANOVA and Duncan's test among different treatment at the same germination time $(P<0.05)$. seeds have moderate adaptabilities to salt concentrations among Amaranthus species. Salt resistance trends of Amaranthus palmeri seeds are similar to those of Amaranthus cruentus [33, 54, 55], stronger than those of Amaranthus retroflexus, Amaranthus blitoides, and Amaranthus albus, and weaker than those of Amaranthus tricolor and Amaranthus giganticus [33, 35, 36, 56]. In salinized areas, Amaranthus palmeri has a higher invasive potential than Amaranthus retroflexus.

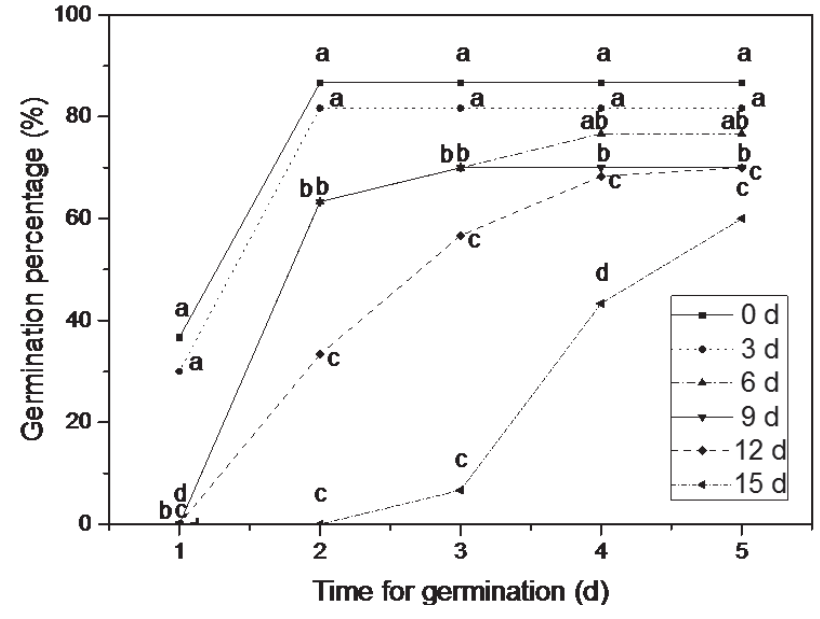

Fig. 5. Germination curve of Amaranthus palmeri seeds under different artificial aging time within 5 days, lowercase letters in the figure are results from ANOVA and Duncan's test among different treatment at the same germination time $(P<0.05)$.

Table 5. Seed germination and seedling growth indices as well as vigor of Amaranthus palmeri under different salt concentrations.

\begin{tabular}{|c|c|c|c|c|c|c|c|c|}
\hline SC g/L & GP $\%$ & GR $\%$ & GI & HL mm & RL mm & SL mm & RRH & VI \\
\hline 0 & $36.7 \pm 2.9 \mathrm{a}$ & $85.0 \pm 0.0 \mathrm{a}$ & $60.8 \pm 1.4 \mathrm{a}$ & $25.47 \pm 3.95 \mathrm{a}$ & $28.47 \pm 2.04 \mathrm{~b}$ & $54.28 \pm 4.75 \mathrm{a}$ & $1.16 \pm 0.19 \mathrm{~b}$ & $3300 \pm 271 \mathrm{a}$ \\
\hline 4 & $38.3 \pm 10.4 \mathrm{a}$ & $71.7 \pm 7.6 \mathrm{~b}$ & $51.9 \pm 8.1 \mathrm{a}$ & $24.90 \pm 5.06 \mathrm{a}$ & $35.90 \pm 5.44 \mathrm{a}$ & $60.76 \pm 9.10 \mathrm{a}$ & $1.48 \pm 0.31 \mathrm{~b}$ & $2911 \pm 514 \mathrm{a}$ \\
\hline 8 & $0.0 \pm 0.0 \mathrm{~b}$ & $10.0 \pm 0.0 \mathrm{c}$ & $2.9 \pm 0.7 \mathrm{~b}$ & $7.14 \pm 8.50 \mathrm{~b}$ & $9.62 \pm 5.39 \mathrm{c}$ & $16.76 \pm 13.78 \mathrm{~b}$ & $2.40 \pm 1.41 \mathrm{a}$ & $42 \pm 34 \mathrm{~b}$ \\
\hline
\end{tabular}

* $\mathrm{SC}=$ Salt concentration, $\mathrm{GP}=$ Germination potential, $\mathrm{GR}=$ Germination rate, $\mathrm{GI}=$ Germination index, $\mathrm{HL}=\mathrm{Hypocotyl}$ length, $\mathrm{RL}=$ Radicle length, $\mathrm{SL}=$ Seedling length, $\mathrm{RRH}=$ Ratio of radicle length to hypocotyl length, $\mathrm{VI}=$ vigor index. 
Table 6. Growth and vigor indices of Amaranthus palmeri seedlings under different artificial aging time.

\begin{tabular}{|c|c|c|c|c|c|c|}
\hline TAAd & HL mm & RL mm & SL mm & SFW mg & RRH & VI \\
\hline 0 & $23.5 \pm 2.3 \mathrm{a}$ & $18.3 \pm 3.6 \mathrm{~b}$ & $41.7 \pm 4.8 \mathrm{~b}$ & $3.96 \pm 0.06 \mathrm{a}$ & $0.78 \pm 0.15 \mathrm{~d}$ & $2577 \pm 348 \mathrm{~b}$ \\
\hline 3 & $22.8 \pm 3.8 \mathrm{a}$ & $30.2 \pm 6.5 \mathrm{a}$ & $53.0 \pm 9.0 \mathrm{a}$ & $3.51 \pm 0.18 \mathrm{~b}$ & $1.34 \pm 0.27 \mathrm{c}$ & $2955 \pm 484 \mathrm{a}$ \\
\hline 6 & $17.0 \pm 3.3 \mathrm{~b}$ & $22.6 \pm 6.2 \mathrm{~b}$ & $39.6 \pm 8.6 \mathrm{~b}$ & $3.35 \pm 0.10 \mathrm{~b}$ & $1.34 \pm 0.32 \mathrm{c}$ & $1413 \pm 332 \mathrm{c}$ \\
\hline 9 & $16.0 \pm 4.5 \mathrm{~b}$ & $21.5 \pm 6.1 \mathrm{~b}$ & $37.6 \pm 9.7 \mathrm{~b}$ & $2.89 \pm 0.07 \mathrm{c}$ & $1.37 \pm 0.28 \mathrm{c}$ & $1271 \pm 363 \mathrm{c}$ \\
\hline 12 & $10.6 \pm 4.8 \mathrm{c}$ & $19.9 \pm 6.2 \mathrm{~b}$ & $30.5 \pm 9.6 \mathrm{c}$ & $2.30 \pm 0.07 \mathrm{~d}$ & $2.08 \pm 0.80 \mathrm{~b}$ & $847 \pm 271 \mathrm{~d}$ \\
\hline 15 & $5.2 \pm 2.9 \mathrm{~d}$ & $13.5 \pm 3.8 \mathrm{c}$ & $18.7 \pm 5.9 \mathrm{~d}$ & $2.10 \pm 0.08 \mathrm{e}$ & $3.00 \pm 1.20 \mathrm{a}$ & $274 \pm 87 \mathrm{e}$ \\
\hline
\end{tabular}

* TAA = Time of artificial aging, $\mathrm{HL}=$ Hypocotyl length, $\mathrm{RL}=$ Radicle length, $\mathrm{SL}=$ Seedling length, $\mathrm{RRH}=$ Ratio of radicle length to hypocotyl length, $\mathrm{VI}=$ vigor index.

\section{Effects of Different Artificial Aging Time on Amaranthus palmeri Seed Germination and Seedling Growth}

After artificial aging at $50^{\circ} \mathrm{C}$ and $100 \%$ humidity for 3 to 15 days, Amaranthus palmeri seed curves showed obvious separation (Fig. 5); seed germination was delayed after aging for more than 6 days, while GR was decreased after aging for more than 9 days $(P<0.05)$. GR was inhibited with increasing aging time, reaching $69 \%$ of the GR of the control group after 15 days of aging.

The fresh weight of seedlings of Amaranthus palmeri was inhibited after seeds artificial aging for 3 days, while the ratio of radicle to hypocotyl length was promoted (Table 6). The hypocotyl length and VI of Amaranthus palmeri seedlings were significantly inhibited after seeds artificial aging for 6 days, and all growth indices were significantly inhibited for 15 days $(\mathrm{p}<0.05)$.

There is a correlation between the viability of Amaranthus palmeri seeds and vigor during artificial aging. After 3 years of naturally existing in soils in Nebraska, vigor of Amaranthus palmeri seeds was found to be less than $10 \%[19,57]$; after 5 months of waterflooding, their vigor was found to be $86 \%$ [18]. Therefore, Amaranthus palmeri seeds exhibit a certain tolerance to short-term high temperatures and high humid environments $[58,59]$. The effect of time and temperature on the viability of Amaranthus palmeri seeds is greater than that of humidity. Exposure to high temperatures for long periods of time can inhibit Amaranthus palmeri seed viability in soil seed banks.

Compared to the population in the United States, some adaptive changes have been reported in Amaranthus palmeri in China. For example, germination abilities at high temperatures as $40^{\circ} \mathrm{C}$ and growth potential at $25^{\circ} \mathrm{C}$ are improved, while seed germination speed and seedling growth are inhibited by light. The reasons for these differences are not clear, and should be evaluated further.

\section{Conclusions}

Amaranthus palmeri seed germination exhibits the following characteristics: preference for hot and humid environments, poor adaptability to light, moderate drought and salt resistance when compared to other Amaranthus species. Moreover, seed bank persistence could be destroyed gradually by high temperature and humidity. It can be predicted that the wild Amaranthus palmeri in Tianjin has high invasion potential from North China, central China to South humid and hot areas, also has the risk of spreading northward under the trend of global warming.

\section{Acknowledgments}

We thank Mei Zhang, Pufan Zheng for finding the populations of Amaranthus palmeri and breeding the plant.

\section{Conflict of Interest}

The authors declare no conflict of interest.

\section{References}

1. Announcement on the release of the list of alien invasive species in China's natural ecosystem (the fourth batch), Available online: http://www.mee.gov.cn/gkml/hbb/ bgg/201612/t20161226 373636.htm (accessed on 20 Dec. 2016).

2. HORAK M.J., LOUGHIN T.M. Growth analysis of four Amaranthus species. Weed Science. 48 (3), 347, 2000.

3. KORRES N.E., NORSWORTHY J.K., FITZSIMONS T., ROBERTS T.L., OOSTERHUIS D.M. Differential response of palmer amaranth (Amaranthus palmeri) gender to abiotic stress. Weed Science, 65 (2), 213, 2017.

4. SELLERS B.A., SMEDA R.J., JOHNSON W.G., ELLERSIEK M.R. Comparative growth of six Amaranthus species in Missouri. Weed Science, 51 (3), 329, 2003.

5. SOSNOSKIE L.M., WEBSTER T.M., GREY T.L., CULPEPPER A.S. Severed stems of Amaranthus palmeri 
are capable of regrowth and seed production in Gossypium hirsutum. Ann Appl Biol, 165(1): 147, 2014.

6. WEBSTER T.M., GREY T.L. Glyphosate-Resistant palmer amaranth (Amaranthus palmeri) morphology, growth, and seed production in Georgia. Weed Science, 63 (1), 264, 2015.

7. DOUGLAS J.S. The biology and management of pamer amaranth (Amaranthus palmeri S. Wats) in Indiana. Purdue University: West Lafayette, Indiana, 2016.

8. EHLERINGER J. Ecophysiology of Amaranthus palmeri, a sonoran desert summer annual. Oecologia, 57 (1-2), 107, 1983.

9. DAVIS A.S., SCHUTTE B.J., HAGER A.G., YONG B.G.. Palmer amaranth (Amaranthus palmeri) damage niche in Illinois soybean is seed limited. Weed Science, 63 (3), 658, 2015.

10. KISTNER E.J., HATFIELD J.L. Potential geographic distribution of Palmer Amaranth under current and future climates. Agricultural \& Environmental Letters, 3 (1), $1,2018$.

11. LI Z.Y. Amaranthus palmeri S. Watson, a newly naturalized species in China. Chinese Bulletin of Botany, 20 (6), 734, 2003.

12. MO X.Q., MENG W.Q., LI H.Y. New distribution records of three species of exotic plants in Tianjin: Amaranthus palmeri, Ipomoea lacuuosa and Aster subulatus. Journal of Tianjin Normal University (Natural Science Edition), 37 (2), 36, 2017.

13. MA J.S. The Checklist of the Chinese invasive plants, 1st ed.; Publisher: Higher Education Press, China, 28, 2013 [In Chinese].

14. YAN J., YAN X.L., WANG Z.H., LI H.R., MA J.S. New records of five species of alien plants in Anhui Province. Journal of Plant Resources and Environment, 24 (3), 109, 2015.

15. JI M.J., HUANG Z.F, CUI H.L., CHEN J.C., YU H.Y., ZHANG J.P., LI X.J. A New imazethapyr - resistant population of Amaranthus palmeri. Journal of Weed Science, 38 (3), 23, 2020.

16. REZWANA A., ZAFAR A.R., SNOBER J., IRFAN R. Biology of Amaranths. The Botanical Review, 83 (4), 382, 2017.

17. BENSCH C.N., HORAK M.J., PETERSON D. Interference of redroot pigweed (Amaranthus retroflexus), palmer amaranth (A. palmeri), and common waterhemp (A. rudis) in soybean. Weed Science, 51 (1), 37, 2003.

18. FRANCA L.X., DODDS D.M., REYNOLDS D.B., BOND J.A., MILLS A., CATCHOT A.L., PETERSON D.G.. Influence of flooding period and seed burial depth on Palmer amaranth (Amaranthus palmeri) seed germination. Pest Management Science, 76 (11), 3832, 2020.

19. KORRES N.E., NORSWORTHY J.K., YORNG B.G., REYNOLDS D.B., JOHNSON W.G., CONLEY S.P., SMEDA R.J. MUELLER T.C., SPAUNHORST D.J., GAGE K.L., LOUX M., KRUGER G.R., BAGAVTHIANNAN M.B. Seedbank persistence of palmer amaranth (Amaranthus palmeri) and waterhemp (Amaranthus tuberculatus) across diverse geographical regions in the United States. Weed Science, 66 (4), 1, 2018.

20. LI H.Q., ZHAO L., ZHU P.W., ZHANG Y., ZHU G.P., LIU Q. Potential distribution of invasive palmer amaranth (Amaranthus palmeri) in China. Journal of Tianjin Normal University (Natural Science Edition), 35 (4), 57, 2015.

21. ZHANG M.L., ZUO J., XIAO X.Q. Risk Control of Amaranthus palmeri invasion in Changsha. Modern Agricultural Science and Technology, 5, 193, 2019
22. CHAHAL P.S., JHALA A.J. Economics of management of Photosystem II- and HPPD-inhibitor-resistant Palmer amaranth in corn. Agronomy journal, 110 (5), 1905, 2018.

23. VILA-AIUB M. M., GOH S.S., GANINES T.A., HAN H., BUSI R., YU Q., POWLES S.B. No fitness cost of glyphosate resistance endowed by massive EPSPS gene amplification in Amaranthus palmeri. Planta, 793 (4), 239, 2014.

24. STEINMAUS S.J., PRATHER T.S., HOLT J.S. Estimation of base temperature for nine weed species. Journal of Experimental Botany, 51 (343), 275, 2000.

25. PEIGUO G., KASSIM A. Temperature effects on germination and growth of redroot pigweed (Amaranthus retroflexus), palmer amaranth (A. palmeri), and common waterhemp (A. rudis). Weed Science, 51 (6), 869, 2003.

26. JHA P., NORSWORTHY J.K., RILEY M.B., BRIDGES W. Annual changes in temperature and light requirements for germination of palmer amaranth (Amaranthus palmeri) seeds retrieved from soil. Weed Science, 58 (4), 426, 2010.

27. STECKEL L., SPRAGUE C., STOER E.W., WAX L.M. Temperature effects on germination of nine Amaranthus species. Weed Science, 52 (2), 217, 2004.

28. HAO J.H., LV S.S., BHATTACHARYA S., FU J.G. Germination response of four alien congeneric Amaranthus species to environmental factors. Plos One, 12 (1), e0170297, 2017.

29. YE J., WEN B. Seed germination in relation to the invasiveness in spiny amaranth and edible amaranth in Xishuangbanna, SW China. PLOS ONE, 12 (4), e0175948, 2017.

30. CHENG W.X., CHEN S.C., LI W.L. Characterization of seed germination of Amaranthus retroflexus L. Journal of Henan Agricultural Sciences, 38 (11), 94, 2009.

31. IVES R.L. Climate of the Sonoran desert region. Annals of the Association of American Geographers, 39 (3), 143, 1949.

32. CHAHAL P.S., IRMAK S., JUGULAM M., JHALA A.J. Evaluating effect of degree of water stress on growth and fecundity of palmer amaranth (Amaranthus palmeri) using soil moisture sensors. Weed Science, 66 (6), 738, 2018.

33. CE V.C., IDEM K. Effect of salt concentrations on Amaranthus germination under in vitro. Journal of Biotechnology Research, 4 (1), 1, 2018.

34. MACLER B.A., MACELROY R.D. Productivity and food value of Amaranthus cruentus under non-lethal salt stress. Advances in Space Research, 9 (8), 135, 1989.

35. QIN L.F., GUO S.S., AI W.D., TANG Y.K., CHENG Q.Y., CHEN G. Effect of salt stress on growth and physiology in amaranth and lettuce: implications for bioregenerative life support system. Advances in Space Research, 51 (3), 476, 2013.

36. IDRIS L.M., NULIT R., ZAMAN F.Q., ARIFIN K.M. Hydrotime analysis of Amaranthus spp. seed germination under salinity condition. Journal of Applied Research on Medicinal and Aromatic Plants, 17, 100249, 2020.

37. AVILA RT., PAULA N.A., ROBERTO M.H., NOGUEIRA S.V., INGRID G.G., AMARAL V.F. Electrical conductivity and accelerated aging in amaranth (Amaranthus crueentus L.) seeds. Journal of Seed Science, 40 (1), 44, 2018.

38. ZHANG D., ZHANG F.L., YANG Z.R., HAO L.Z., WANG J.Q., REN X.Y. Effects of $\mathrm{Ce}^{3+}$ and $\mathrm{La}^{3+}$ soaking on vigor and physiological characteristics of Allium mongolicum seeds artificially aged. Acta Botanica BorealiOccidentalia Sinica, 40 (1), 87, 2020.

39. FENOLLOSA E., JENE L., MUNNE-BOSCH S. A rapid and sensitive method to assess seed longevity through 
accelerated aging in an invasive plant species. Plant Methods, 16 (1), 24, 2020.

40. BOND J.A., OLIVER L.R.. Comparative growth of palmer amaranth (Amaranthus palmeri) accessions. Weed Science, 54 (1), 121, 2006.

41. WARD S.M., WEBSTER T.M., STECKEL L.E. Palmer amaranth (Amaranthus palmeri): a review. Weed Technology, 27(1), 12, 2013.

42. REINHARDT PISKACKOVA T.A., REBERG-HORTON S.C., RICHATDSON R.J., JENNINGS K.M., FRANCA L., YOUNG B.G., LEON R.G. Windows of action for controlling palmer amaranth (Amaranthus palmeri) using emergence and phenology models. Weed Research, 00: 1. 2021.

43. SCHWARTZ L.M., GIBSON D.J., YOUNG B.G. Do plant traits predict the competitive abilities of closely related species? AoB Plants, 8, plv147, 2015.

44. BERGER S.T., FERRELL J.A., ROWLAND D.L., WEBSTER T.M. Palmer amaranth (Amaranthus palmeri) competition for water in cotton. Weed Science, 63(4), 928, 2015.

45. WEI Y., LI Q., LI Y., MAO Z.X., WANG Y.C., YUE M. Research advances of invasive alien plant Amaranthus retroflexus L. Chinese Journal of Ecology, 39(1),282,2020.

46. BATLLA D., BENECH-ARNOLD R.L. Weed seed and the light environment: implications for weed management. Weed Biology and Management, 14(2), 77, 2014.

47. SCHWARTZ L.M., NORSWORTHY J.K., YOURNG B.G., BRADLEY K.W., KRUGER G.R., DAVIS V.M., STECKEL L.E., WALSH M.J. Tall waterhemp (Amaranthus tuberculatus)and palmer amaranth (Amaranthus palmeri) seed production and retention at soybean maturity. Weed Science, 30 (1), 284, 2016.

48. NORSWORTHY J.K., KORRES N.E., WALSH M.J., POWLES S.B. Integrating herbicide programs with harvest weed seed control and other fall management practices for the control of glyphosate-resistant palmer amaranth (Amaranthus palmeri). Weed Science, 64 (3), 540, 2016.

49. MOOSAVI A., AFSHARI R.T., SHARIF-ZADEH F., AYNEHBAND A. Seed priming to increase salt and drought stress tolerance during germination in cultivated species of Amaranth. Seed Science and Technology, 37 (3), 781, 2009.

50. SKELTON J.J., Ma R., RIECHERS D.E. Waterhemp (Amaranthus tuberculatus) control under drought stress with 2,4-dichlorophenoxyacetic acid and glyphosate. Weed Biology \& Management, 16 (1), 34, 2016.
51. CHAUHAN B., JOHNSON D. Germination ecology of spiny (Amaranthus spinosus) and slender amaranth ( $A$. viridis): troublesome weeds of direct-seeded rice. Weed Science, 57 (4), 379, 2009.

52. KORRES N.E., NORSWORTHY J.K., BRYE K., SKINNER V., MAUROMOUSTAKOS A. Relationships between soil properties and the occurrence of the most agronomically important weed species in the field margins of eastern Arkansas - implications for weed management in field margins. Weed Research, 57 (3), 159, 2017.

53. SEHGAL A., SITA K., BHANDARI K., KUMAR S., KUMAR J., PRASAD P.V., SIDDIQUE K.H., NAYYAR H. Influence of drought and heat stress, applied independently or in combination during seed development, on qualitative and quantitative aspects of seeds of lentil (Lens culinaris Medikus) genotypes, differing in drought sensitivity. Plant Cell Environ. 42 (1), 198, 2019.

54. LUYCKX A., BEGHIN C., QUINET M., ACHADE B., PRODJINOTO H., GANDONOU C.B., LUTTS S., Salinity differently affects antioxidant content and amino acid profile in two cultivars of Amaranthus cruentus differing in salinity tolerance. J Sci Food Agric. https://doi. org/10.1002/jsfa.11272, 2021.

55. MORENO C., SEAL C.E., PAPENBROCK J. Seed priming improves germination in saline conditions for Chenopodium quinoa and Amaranthus caudatus. J Agro Crop Sci. 204 (1),40,2018.

56. SARKER U., OBA S. Salinity stress enhances color parameters, bioactive leaf pigments, vitamins, polyphenols, flavonoids and antioxidant activity in selected Amaranthus leafy vegetables. Journal of the Science of Food and Agriculture, 99 (5), 2275, 2019.

57. ZHANG M., MA K.X., LIU T., TANG L.L., KHAN A.A., YANG T., ZHENG P.F., WANG T.T., HAN J.H., SHI F.C. Responses in phenotypic plasticity of Amaranthus palmeri and Polygonum orientale to soil factors under different habitats. Clean - Soil, Air, Water, 48 (1900203), 1, 2019.

58. SCHWARTZ-LAZARO L.M., GREEN J.K., NORSWORTHY J.K. Seed retention of Palmer amaranth (Amaranthus palmeri) and barnyardgrass (Echinochloa crus- galli) in soybean. Weed Technology, 31 (1), 617, 2017.

59. KHAN I., NAVIE S., GEORGE D., O'DONNELL C., ADKINS S.W. Alien and native plant seed dispersal by vehicles. Austral Ecology, 43 (1), 76, 2018. 